\title{
Uusioersily
}

\section{Gendered Harms and their Interface with International Criminal Law: Norms, Challenges and Domestication}

Ni Aolain, F. (Accepted/In press). Gendered Harms and their Interface with International Criminal Law: Norms, Challenges and Domestication. International Feminist Journal of Politics, 16(4), 622-648.

Link to publication record in Ulster University Research Portal

\section{Published in:}

International Feminist Journal of Politics

Publication Status:

Accepted/In press: 01/01/2014

\section{Document Version}

Author Accepted version

\section{General rights}

Copyright for the publications made accessible via Ulster University's Research Portal is retained by the author(s) and / or other copyright owners and it is a condition of accessing these publications that users recognise and abide by the legal requirements associated with these rights.

\section{Take down policy}

The Research Portal is Ulster University's institutional repository that provides access to Ulster's research outputs. Every effort has been made to ensure that content in the Research Portal does not infringe any person's rights, or applicable UK laws. If you discover content in the Research Portal that you believe breaches copyright or violates any law, please contact pure-support@ulster.ac.uk. 


\section{PROOF COVER SHEET}

Author(s): $\quad$ FIONNUALA NÍ AOLÁIN

Article Title: $\quad$ Gendered Harms and their Interface with International Criminal Law

Article No: $\quad$ RFJP952126

Enclosures: $\quad$ 1) Query sheet

2) Article proofs

Dear Author,

1. Please check these proofs carefully. It is the responsibility of the corresponding author to check these and approve or amend them. A second proof is not normally provided. Taylor \& Francis cannot be held responsible for uncorrected errors, even if introduced during the production process. Once your corrections have been added to the article, it will be considered ready for publication.

Please limit changes at this stage to the correction of errors. You should not make trivial changes, improve prose style, add new material, or delete existing material at this stage. You may be charged if your corrections are excessive (we would not expect corrections to exceed 30 changes).

For detailed guidance on how to check your proofs, please paste this address into a new browser window: http://journalauthors.tandf.co.uk/production/checkingproofs.asp

Your PDF proof file has been enabled so that you can comment on the proof directly using Adobe Acrobat. If you wish to do this, please save the file to your hard disk first. For further information on marking corrections using Acrobat, please paste this address into a new browser window: http:// journalauthors.tandf.co.uk/production/acrobat.asp

2. Please review the table of contributors below and confirm that the first and last names are structured correctly and that the authors are listed in the correct order of contribution. This check is to ensure that your name will appear correctly online and when the article is indexed.

\begin{tabular}{|l|l|l|l|l|}
\hline Sequence & Prefix & Given name(s) & Surname & Suffix \\
\hline 1 & & FIONNUALA Ní & AOLÁIN & \\
\hline
\end{tabular}


Queries are marked in the margins of the proofs, and you can also click the hyperlinks below.

\section{AUTHOR QUERIES}

\section{General points:}

1. Permissions: You have warranted that you have secured the necessary written permission from the appropriate copyright owner for the reproduction of any text, illustration, or other material in your article. Please see http://journalauthors.tandf.co.uk/permissions/usingThirdPartyMaterial.asp.

2. Third-party content: If there is third-party content in your article, please check that the rightsholder details for re-use are shown correctly.

3. Affiliation: The corresponding author is responsible for ensuring that address and email details are correct for all the co-authors. Affiliations given in the article should be the affiliation at the time the research was conducted. Please see http://journalauthors.tandf.co.uk/preparation/ writing.asp.

4. Funding: Was your research for this article funded by a funding agency? If so, please insert 'This work was supported by < insert the name of the funding agency in full $>$ ', followed by the grant number in square brackets '[grant number $\mathrm{xxxx}$ ]'.

5. Supplemental data and underlying research materials: Do you wish to include the location of the underlying research materials (e.g. data, samples or models) for your article? If so, please insert this sentence before the reference section: 'The underlying research materials for this article can be accessed at $<$ full link $>/$ description of location [author to complete]'. If your article includes supplemental data, the link will also be provided in this paragraph. See $<$ http://journalauthors.tandf.co.uk/preparation/multimedia.asp $>$ for further explanation of supplemental data and underlying research materials.

6. The CrossRef database (www.crossref.org/) has been used to validate the references. Mismatches will have resulted in a query.

\begin{tabular}{|c|l|}
\hline QUERY NO. & \multicolumn{1}{c|}{ QUERY DETAILS } \\
\hline AQ1 & $\begin{array}{l}\text { The reference "Cahn et al. 2011" is cited in the text but is not listed in the references } \\
\text { list. Please either delete in-text citation or provide full reference details following } \\
\text { journal style. }\end{array}$ \\
\hline AQ2 & $\begin{array}{l}\text { The reference "Informal Expert Paper 2013" is cited in the text but is not listed in the } \\
\text { references list. Please either delete in-text citation or provide full reference details } \\
\text { following journal style. }\end{array}$ \\
\hline AQ3 & $\begin{array}{l}\text { The reference "Women's Initiatives for Gender Justice 2010" is cited in the text but is } \\
\text { not listed in the references list. Please either delete in-text citation or provide full } \\
\text { reference details following journal style. }\end{array}$ \\
\hline AQ4 & $\begin{array}{l}\text { The reference "Women's Caucus for Gender Justice and the ICC 2010" is cited in the } \\
\text { text but is not listed in the references list. Please either delete in-text citation or provide } \\
\text { full reference details following journal style. }\end{array}$ \\
\hline AQ5 & $\begin{array}{l}\text { The spelling of Name for "Tempkin and Krane 2008" has been changed to "Tempkin } \\
\text { and Krahe 2008" to match the entry in the references list. Please confirm that this is } \\
\text { correct and provide revisions if needed. }\end{array}$ \\
\hline
\end{tabular}




\begin{tabular}{|c|c|}
\hline QUERY NO. & QUERY DETAILS \\
\hline AQ6 & $\begin{array}{l}\text { The Lastpage numbers for "Buss } 2011 \text { " has been replaced using data from CrossRef } \\
\text { and/or PubMed. Please provide a revision if this is incorrect. }\end{array}$ \\
\hline AQ7 & Please provide missing page numbers for the "Kapur 2012" references list entry. \\
\hline AQ8 & $\begin{array}{l}\text { The Reference "Buss 2010; Easteal 2011; Ferme 2013; de Guzman 2011; ICC-01/04- } \\
\text { 01/07-1008-Anx A; Mibenge 2013; Mullins 2009; Nouwen 2013; Oosterveld 2009; } \\
\text { Smart 1989; Snider 1994; Women's Caucus for Gender Justice (WCGJ" are listed in } \\
\text { the references list but is not cited in the text. Please either cite the reference or remove } \\
\text { it from the references list. }\end{array}$ \\
\hline AQ9 & $\begin{array}{l}\text { Please note that the link for Canada in this note does not work. Please check and } \\
\text { update this. }\end{array}$ \\
\hline AQ10 & Should this be a B Heading? \\
\hline
\end{tabular}




\section{How to make corrections to your proofs using Adobe Acrobat/Reader}

Taylor \& Francis offers you a choice of options to help you make corrections to your proofs. Your PDF proof file has been enabled so that you can edit the proof directly using Adobe Acrobat/Reader. This is the simplest and best way for you to ensure that your corrections will be incorporated. If you wish to do this, please follow these instructions:

1. Save the file to your hard disk.

2. Check which version of Adobe Acrobat/Reader you have on your computer. You can do this by clicking on the "Help" tab, and then "About".

If Adobe Reader is not installed, you can get the latest version free from http://get.adobe.com/reader/.

3. If you have Adobe Acrobat/Reader 10 or a later version, click on the "Comment" link at the right-hand side to view the Comments pane.

4. You can then select any text and mark it up for deletion or replacement, or insert new text as needed. Please note that these will clearly be displayed in the Comments pane and secondary annotation is not needed to draw attention to your corrections. If you need to include new sections of text, it is also possible to add a comment to the proofs. To do this, use the Sticky Note tool in the task bar. Please also see our FAQs here: http://journalauthors.tandf.co.uk/production/index.asp.

5. Make sure that you save the file when you close the document before uploading it to CATS using the "Upload File" button on the online correction form. If you have more than one file, please zip them together and then upload the zip file.

If you prefer, you can make your corrections using the CATS online correction form.

\section{Troubleshooting}

Acrobat help: http://helpx.adobe.com/acrobat.html

Reader help: http://helpx.adobe.com/reader.html

Please note that full user guides for earlier versions of these programs are available from the Adobe Help pages by clicking on the link "Previous versions" under the "Help and tutorials" heading from the relevant link above. Commenting functionality is available from Adobe Reader 8.0 onwards and from Adobe Acrobat 7.0 onwards.

Firefox users: Firefox's inbuilt PDF Viewer is set to the default; please see the following for instructions on how to use this and download the PDF to your hard drive: http://support.mozilla.org/ en-US/kb/view-pdf-files-firefox-without-downloading-them\#w_using-a-pdf-reader-plugin 


\title{
Gendered Harms and their Interface with International Criminal Law
}

\author{
FIONNUALA NÍ AOLÁIN
}

University of Minnesota, USA

\section{Abstract}

Many feminists have questioned the extent to which the law can ever effectively deter violence against women given the ways in which the law and criminal justice systems often act to reinforce deeply sexist assumptions about women, their sexual and social identities and their relation to the social (male) world. While acknowledging law's ineffectiveness in fundamentally reordering social relations, a number of scholars and policy makers believe that it is an institution that can be used to make substantive gains for women. The agreement by states on the establishment of an International Criminal Court (ICC), combined with a Statute that augments international legal prohibitions on violence against women, has given traction to optimistic views on international criminal law's capacity to proactively address female specific harms. Moreover, there is confidence that transformative international legal norms will, in turn, enable and support domestic law's capacity to advance accountability for violence against women. In that context, this article considers the potential for proactive and gender-centered complementarity under the ICC system. Based on a systematic review of a wide range of domestic legislation enacted by States Parties following signature and ratification of the ICC Statute, the analysis considers the significance and ramifications of domestic legal changes for the operation of the ICC complementarity system. Detailed consideration is given to ways in which the ICC complementarity regime might be operationalized to ensure a gendered understanding of the "unwilling and unable" standard contained in Article 17 of the ICC

${ }^{\dagger}$ Parts of this article have been previously presented at the Institute of Advanced Studies International Criminal Law Conference in Jerusalem, Israel on 22 December 2011, and at the Robina Conference on Rethinking Sexual Offences, Minneapolis, Minnesota, 5- 6 April 2013. Thanks to Griffin Ferry for research assistance. 
Statute. I further address the extent to which optimism around domestic legal enforcement is warranted, and what pitfalls may follow from a reliance on international criminal law to spearhead normative developments addressing gender violence.

Keywords

international criminal law, gender-based harms, sexual violence, complementarity

Many feminists question the extent to which the law can ever effectively deter violence against women given the ways in which the law and criminal justice systems reinforce deeply sexist assumptions about women, their sexual and social identities and women's relation to the social (male) world (Freeman 1980). For some, "the law," as a fundamentally patriarchal institution, corrupts feminist engagement to its purposes. For this reason, Snider $(1998,11)$ has suggested that "[c]riminal justice systems are probably the least effective institutions to look to for transformative change." While acknowledging that law is often ineffective in reordering social relations, some scholars still maintain that it is an institution that can be used to make substantive gains for women. Expansion of the normative definitions of international crimes added to enlarged sexual violence jurisprudence has produced buoyant optimism on international criminal law's (ICL) capacity to challenge gendered assumptions, address gender-specific harms and encourage the normative advancements realized internationally to be "brought home" and domesticated by states that have ratified the Rome Statute. As ICL becomes absorbed by and/ or influences domestic legal systems, it is reasonable to ask whether its normative content has the capacity to help tackle socially-entrenched violence against women. Can ICL unblock a perceived lack of success in reforming "home-grown" domestic legal norms, and if so, how would we measure that move? This article considers in a preliminary way the relationship between the domestic and the international following the establishment of the International Criminal Court (ICC). My focus is on domestic legislation addressing a wide range of gender-based harms, probing in particular what domesticlevel changes mean for the ICC complementarity regime. The analysis is situated in an acknowledgment of some triumphs for feminist ICL advocacy, but argues that a more partial success story should be told both for ICL's advances and for the domestic effects of feminist ICL advocacy.

The article specifically contemplates an apparent windfall in domestic norm creation for gendered harms in the legal systems of state signatories to the ICC Statute. For this purpose I have systematically tracked a range of legislative enactments broadly addressing violence against women arising postratification in 122 states that are signatories to the ICC. ${ }^{1}$ My approach is to address the slew of domestic enactments as a way to consider how complementarity might be conceptualized and operationalized for gender-based harms under the ICC system. The first part of the article surveys the development of ICL and considers its "capture" capacity for gender-based harms. The analysis briefly addresses what pitfalls may follow from a reliance on ICL to 
spearhead normative developments addressing gendered violence. These pitfalls are a cautionary backdrop to overenthusiasm about the likelihood of domestic transformation. The second part contemplates, in a preliminary way, the relationship between broadly-constructed domestic legislation that may go toward ending impunity for gender-based harms as it relates to the ICC Statute complementarity system. To assess an emerging synergy between state ratification of the ICC Statute and domestic legislation addressing sex-based harms against women, I rely on my survey of states' legislative initiatives that follow subsequent to ICC ratification (Appendix I). This preliminary survey of 122 States Parties to the ICC Statute demonstrates apparently significant domestic legislative movement on gender-based violence in the aftermath of treaty signature. The article explores what such practices signify, and in particular the extent to which the operation of domestic legislation addressing a wide variety of gender-based harms will be relevant to 105 assessing the adequacy of a state's discharge of its responsibilities under the ICC complementarity regime. This section teases out the likely dimensions of the "unwilling and unable" standard under the ICC complementarity system. I address how enlarged domestic regulation influences the complementarity regime, and ponder how such domestic developments enable states to "get their house in order" to meet their Rome Statute obligations. The third part of the article addresses what theoretical and policy implications can be read from the survey of state practice, with particular reference to both the positive and negative dimensions of reliance on criminal law to dismantle the sustained realities of gender-based harm.

\section{INTERNATIONAL CRIMINAL LAW: A BRIEF GENDERED TELLING}

Much can be said about the development of ICL and its recent attention to 120 sexual violence. In broad terms, while the development of a comprehensive legal sanction for sexual violence during warfare has taken decades (Boister and Cryer 2008), there is a positive progress narrative that can be relayed from the end of the Cold War onward (Cahn, Haynes, and Ni Aolain 2011). Until the passage of the ICC Statute, specific international legal prohibition 125 of the crime of rape in situations of armed conflict was found in the Fourth Geneva Convention, ${ }^{2}$ and within Articles 76(1) and 85 of the First Protocol Additional to the Geneva Conventions. ${ }^{3}$ The prohibitions contained in the Geneva Conventions defined rape primarily as an offense against honor. Many have understood the historical narrative as illustrating that all130 encompassing sexual crimes against women were historically excluded from legal prohibition under the laws of war, and when included were only as facets of male status violation. As the attention of states turned to the creation of the ad hoc Criminal Tribunals in Rwanda (ICTR) and the Former Yugoslavia (ICTY), feminist observers were concerned that the low status of existing prohibitions for sexual violation within the hierarchy of humanitarian law 
offenses would infiltrate the mandate of the Tribunals (Pratt and Fletcher 1994). The ad hoc Tribunals partially forced legal and policy conversations concerning sexual violence and its regulation by the Law of Armed Conflict (Meron 1993). Feminist advocates argued that, as the inheritors to an incomplete Nuremberg and Tokyo legacy, the Tribunals should acknowledge and incorporate the gravity of sexual offences into their substantive law. An extraordinary advocacy effort was directed at addressing women's experiences of war and conflict and inserting them into the material scope of application engaged by the post-Cold War International Tribunals.

145 The Statutes of the ad hoc Tribunals (ICTY and ICTR) ultimately recognized specific forms of sexual harms as violations of the laws of war. The push for accountability was followed through in a number of site-specific contexts (e.g. Cambodia and Sierra Leone) as hybrid Tribunals confirmed the cantering pace of ICL enforcement. These Courts have produced a substantive jurispru150 dence addressing sexual violence experienced by men and women in war. The ICTY in Tadić, ${ }^{4}$ Celebici, ${ }^{5}$ Furundzija, ${ }^{6}$ Kunarac and Krstic held, ${ }^{7,8}$ inter alia, that crimes against men constitute sexual harm in international law; that the act of rape can constitute torture under international law; that consent must be assessed in the context of surrounding circumstances; and 155 that a single act of rape in the context of a widespread attack can constitute a crime against humanity. The ICTR in such cases as Akayesu, ${ }^{9}$ Kayishema and Ruzindana, ${ }^{10}$ Barayagwiza, Ngeze and Nahimana, and Gacumbitsi has found that rape can be a constitutive act of genocide under international law and articulated the ways and means whereby the sexualization of Tutsi women was part of the genocidal campaign against all Tutsi. ${ }^{11,12}$ The Sierra Leone Tribunal in Brima, Kamara and Kanu decided that forced marriage was an inhumane act constituting a crime against humanity. ${ }^{13}$ This advocacy effort has been critically described by Nesiah as the arrival of "international conflict feminism” as a player in global power politics (Nesiah 2013, 217).

165 While there is much to be lauded about norm augmentation, contemporary feminist concern is not generally directed at the pace and doctrinal content of ICL and international humanitarian law (IHL) prohibitions. Rather, feminist concern emerges around the "lost in translation effect," as the under- or inadequate enforcement of new norms raises old specters of unseen hierarchies operating to the detriment of addressing harms experienced by women.

The complexity of international conflict feminism's political and legal activism has leaked from criminal accountability to the peace and security agenda of the United Nations Security Council (UNSC), ultimately resulting in the production of a number of UNSC Resolutions on gender, peace and security. All resolutions bear the motif of acknowledging sexual harms, promoting criminal accountability and creating incentives for states to include women in accountability conversations. The core regulatory preoccupation has been with sexual violence and, in particular, the harm of rape (Engle 2012). In particular, the rape prohibition has reaped the most international legal and policy "action."

180 It cannot be denied that the emphasis on criminal accountability for sexual 
harms has borne extraordinary fruit for feminist advocates. There are, however, costs to such a strategy, including the elevation of sexual violence as the primary harm against women, and the collapse of a collective international conscience to that end. Moreover, early jurisprudential success in a small number of cases has not transformed the landscape of accountability for sexual harms in conflict. Critiques of the failure to fully and adequately prosecute sexual crimes have an obvious fault line, with the reasons commonly identified for the miserable success in state-level prosecutions of gendered violence. ${ }^{14}$ Thus, knowledge sharing from domestic legal systems concerning the challenges of adequately prosecuting crimes of sexual violence is highly relevant to the potential of indictment, prosecution and conviction at the international level. Under-enforcement of the prohibitions on harms against women has emerged in multiple guises. A key point underscored by Chappell, Grey, and Waller (2013) is that the relationship between informal 195 and formal rules in institutional settings can often serve to undermine theoretically-positive moves to undo gender hierarchies and exclusions. There is an underlying concern for many scholars that sometimes making rape visible is deceptively easy in the context of atrocity, and that there are real dangers to this strategy (Enloe 2004).

There is substantial imagination capture by wartime rape. This results in the splintering of impunity discourses on sexual violence - lodging conflict rape in the "extra-ordinary" violence of wartime atrocity - divorcing conflict rape conceptually from the lived experience of routine sexual violence and facilitating the easy dislocation of one kind of harm from the other. Increasingly, scholars pause and reflect on the pluralism articulated by international courts and wonder if the naming has overtaken enforcement, and whether the former becomes the means to deflect attention from the latter; namely the ongoing, systematic violence against women (whether in wartime or peacetime). This is connected to "growing feminist unease about the gap 210 between the ostensible feminist gains in international law and the actual impact of international law on women's daily lives" (0'Rourke 2013a, 4). The limits of enforcement are evident when we examine the patchwork and ad hoc nature of domestic enforcement for criminal sexual harm in most domestic legal systems.

\section{THE INTERATIONAL CRIMINAL COURT INHERITS THE MANTLE}

The agreement by states on a Statute for the ICC, ${ }^{15}$ the requisite number of ratifying states and the appointment of a Prosecutor issuing indictments confirm a trend of criminalizing sexual harms that continues domestically and internationally. The broad subject matter jurisdiction (jurisdiction ratione materiae) of the ICC applies with respect to crimes that belong to one of the categories of crimes included in the ICC Statute: namely, the crime of genocide, crimes against humanity, war crimes and the crime of 
aggression. The Statute expands the definition of crimes against humanity and war crimes to explicitly recognize rape, and includes sexual slavery, enforced prostitution, forced pregnancy, enforced sterilization and trafficking in times of peace as well as war, ${ }^{16}$ when such violence is widespread or systematic and the product of state or organizational policy (Copelon 2003).

One consequence of ICC ratification is the incentives that follow to prosecute the Statute-defined crimes domestically and support the mandate of the Court. Significant ink has been spilt on the broader compliance consequences of the ICC, but much less attention has been paid to the gendered implications of ICC signature and ratification for states, and specifically how it may affect the domestic regulation of sex crimes and sexual harms. I highlight two particular consequences. The first is the creation of, or general modification to, broadly-based domestic war crimes statutes and/or criminal law norms facilitating the prosecution of war crimes, genocide and crimes against humanity by States Parties. This domestication may (or may not) implicate gender-sensitive normative alterations to the existing law of signatory states. At the very least it encourages the articulation of gendered harms contained in the Statute into the domestic law of States Parties. ${ }^{17}$

The degree of influence of this domestic absorption will vary and much will ultimately depend on the interpretation of domestic legislation by domestic courts. This may turn in part on the willingness and the capacity of national courts to use the jurisprudence of the ad hoc Tribunals and the ICC as relevant and guiding interpretation for national legislation. For example, it remains to be seen whether the importation of crimes of genocide and crimes against humanity necessarily introduces notions of "genocidal rape" or other similarly judicially-developed doctrines into the domestic legal systems of signatory states. Obviously the translation of abstract international legal norms to domestic configuration may not be entirely straightforward. While some states may practice a form of constitutional fidelity to the language of the Rome 255 Statute, others may produce a loss in translation effect as international norms journey to domestic legal forms. This process mirrors the translation of international human rights law norms to domestic form, where the challenges involved in translating gender equality into local vernaculars have been well documented (Merry 2006).

260 A second consequence of ratification is some evidence of significant modifications to an array of domestic norms related to sexual violence, trafficking, stalking and domestic violence in states that have ratified the ICC Statute. Evidently, not all of these legislative enactments follow directly from the provisions of the ICC Statute; stalking and trafficking being the obvious 265 examples. They are nonetheless included in my legislative tracking to explore the idea that the effects of international legal norms on compliance are inherently complex and may interact with domestic processes of norm change already in place or assisted by external prompts. International law "[m]ay shape or affect the terms of bargains or transactions between nonstate actors, who are not even directly bound by the rules in question" 
(Howse and Teitel 2010, 132). Domestic legislative enforcement can evidently operate in the "shadows" of international law, shaped by and responsive to it in direct as well as subtle ways. Thus, the flurry of legislative activity involving gender harms in general and sexual harm in particular following ICC ratification may indicate some broader leverage on sexual harm regulation from the impetus and context generated by ICC obligations. Specifically, greater domestic regulation may influence the ICC complementarity regime, and I suggest that such domestic developments enable states to "get their house in order" to meet their Rome Statute obligations.

Complementarity: Gender Norms and Diffusion Theory as Applied to ICL and Domestic Legal Norms on Violence against Women

Central to broad-based accountability for gender crimes under the ICC system will be the capacity to engage active and functional complementarity. Complementarity emerged relatively early in the negotiating process of the ICC Statute. Moreover, the details of the complementarity regime proved particularly contentious throughout the course of the negotiations (Kleffner 2008). States argued that the unique characteristics of the ICC as a permanent institution with prospective jurisdiction that extended to crimes committed in the territory or by nationals of States Parties had to be balanced against state sovereignty and state interest. This meant creating an internal constraint on the power of the court, as well as giving states the opportunity to address breaches first. Complementarity advocacy was framed by pragmatic assessments of efficiency and effectiveness, given that states generally have the best access to evidence and witnesses, as well as the resources necessary to cope with a large number of cases (Informal Expert Paper 2013).

Inherent in the mandate of complementarity is the capacity for "proactive" complementarity (Burke-White 2008). For gender-based violence, this could minimally translate into the ICC's assistance and encouragement to states undertaking domestic criminal prosecutions. Such support could have an overall and positive influence on the successful prosecution of sex crimes at the domestic level (Burke-White 2008). However, basing proactive complementarity solely on technical ICC capacity building would be an impoverished program for addressing gender-based violence. Clearly, how and if complementarity will be read through a gender-sensitive lens remains entirely unclear. The core of complementarity lies in the concept of "unwilling or unable to prosecute" standard (Article 17(1)). The Women's Caucus for Gender Justice has maintained that a state should be deemed "unable" when it has failed to genuinely investigate and prosecute sexual and gender-based violence (Women's Initiatives for Gender Justice 2010). In assessing this criterion, the Court has some guidance from the Statute, including: whether the purpose of the national proceedings was to shield the person from liability; whether there has been an unjustified delay in proceedings; or the actions of the state are otherwise inconsistent with bringing a person to justice (El Zeidy 2002). 
In two recent admissibility decisions from the ICC, guidance emerges on these standards. ${ }^{18}$ The Court highlights two questions that follow from an admissibility challenge; namely whether there is an ongoing investigation or prosecution, and if the state is "genuinely" unwilling or unable to carry out such investigation or prosecution. In the Gaddafi case the Court stressed the significance of "concrete and progressive" steps to ascertain individual responsibility, as well as the identification of "concrete and tangible evidence of a sufficient degree of specificity and probative value" by the local legal system. ${ }^{19}$ The inability standard emerging from the highly fraught post-con325 flict Libyan site is concentrated on matters of territorial control, capacity to obtain testimony and availability of legal representation to the accused. Applying a gendered lens, it seems reasonable to inquire whether a standard of "genuineness" is gender neutral; namely whether the Court would compare the progress and expectation of gender-based crimes with standard 330 operating procedures in other crimes. Here the uniformity of domestic approaches would seem critical to advancing gender parity under the "unwilling or unable" standard.

A realistic assessment of complementarity in domestic legal systems requires a sober recognition of the lacunae in processing gender crimes. This realistic assessment is imperative given the relative lack of attention to the implications of complementarity for broadly-based gender justice. These accountability gaps are particularly evident in the pursuit of formal post-conflict justice accountability. It remains an open question whether the absence or limited inclusion of gender violence in domestic investigations and/or indict340 ments will be seen as activating the "unwilling or unable" standard of the ICC Statute. It has been argued that where gender-based "[c]rimes are not defined and/or punished as grave crimes or where procedural or evidentiary requirements particular to sexual violence preclude or unreasonably obstruct a proper conviction," the unavailability of the national judicial system has 345 been implicated (Women's Caucus for Gender Justice and the ICC 2010, 25). More broadly, will structural exclusion and marginality for gendered violence in state criminal justice systems trigger the "unable and unwilling" standard? Structural exclusion may be prompted by the absence of specific legislation criminalizing crimes contained in the ICC Statute. Notably, the ICC Gaddafi

350 case admissibility decision found that lack of legislation criminalizing crimes against humanity did not per se render the case at hand admissible. But, given the historic lacunae in regulating gender-based violence, feminist activists may still seek to insist that the failure to implement the Rome Statute crimes into domestic law (including the failure to incorporate gender crimes or inadequately incorporating them) should constitute an identified breakdown in terms of proactive and functional complementarity in the context of gendered crimes. Arguably, a broader web of domestic tolerance for sexual harms and the absence of sustained regulation for a variety of gender-based harms could be viewed as implicating the "unwilling or unable" standard. 
Thus, a central question is what will count toward actually establishing the "unwilling or unable" standard? Should this evaluation include the barriers created by substantive and procedural rules that discriminate along gender lines (e.g. the status of female testimony and access to gender-sensitive court procedures such as in-camera evidence giving; Kapur 2012)? Moreover, whether the unavailability of national legal process will include the gendered effects of an insecure environment and its consequences for accountability remains an open question. Paying attention to normative factors, such as amnesty or immunity laws, requires asking whether the immunities should be assessed from a gender-centered perspective rather than assuming that all amnesties function equally for all.

\section{DOMESTIC ENGAGEMENT WITH GENDERED HARMS}

As the tracking of state ratification of the ICC Statute and subsequent legislation shows, of the 122 States Parties studied for this analysis only 27 have not introduced any subsequent domestic legislation that generally addresses violence against women. The vast majority of states reviewed for this preliminary study have produced multiple pieces of national legislation addressing a range of harms, including violence against women, domestic violence, marital rape, sexual harassment, trafficking, stalking, female genital mutilation and early marriage. Many states have produced multiple and sequential changes to national legislation addressing violence against women in what seems to be a progressively expanding practice of regulatory enthusiasm. These include such diverse countries as Georgia, Guyana, Kenya, Ireland, Mexico and Zambia. Only distinct country-specific and comparative analysis will yield data on the faithfulness of the translation from ICL norms, or indeed progressive/expansive development beyond the state-agreed content of the ICC 390 Statute. However, the central point of this analysis is not that domestic norm development is necessarily an outworking of the ICC - only further country-level research with reveal those links - but rather that these norms will be central to the exercise of effective complementarity in the signatory states. As states put in place broader institutional and normative mechanisms to address gender-based violence, I argue that such augmentations will be intertwined with the practice and assessment of effective complementarity. National legal capacity to name, regulate and process gender-based violence builds domestic capacity in ways that support complementarity (or may limit for better or worse the reach of the ICC to national sites). As a consequence, feminist critical-reflective perspectives are emerging, revealing how ICL could usefully redirect analysis to the question of positive norm transfer between ICL and domestic cases of transitional justice (O'Rourke 2013b).

In assessing domestic legislative enactments, evidently domestic legal changes may well have been long in the making and it may be merely coinci- 
dental that ratification and domestic reform overlap. To wit, a number of the cases illustrated in Appendix 1 demonstrate time lags between local legislate enactments and ICC ratification. This confirms that parallel domestic advocacy and legal transformation initiatives may be the drivers in producing domestic norm proliferation. However, it is plausible that ratification of the ICC creates an opportunity (and arguably some push toward conformity in terms of treaty compliance) to remedy contradictory domestic norms. Moreover, remedying these gaps may be the means whereby states will deliver on their complementarity obligations. Remedial domestic action allows for the gaps in domestic accountability to be addressed and make it more likely that states will have available a substantive normative basis to address gender-based violence.

A separate matter is to what degree domestic norm production produces wholly positive outcomes for women. Some feminists have raised meaningful concerns about the extent to which an unrelenting emphasis on penetrative sexual violence has operated to exclude attention to the conditions conducive to the production of systematic violence (de Londras 2011). An important question is whether there is "healthy norm transfer" occurring between the domestic and international: to what extent are feminist lessons learned domestically transferred to the international sphere, and what kinds of lessons about prosecuting sexual violence will be transferred from the international proceedings to the reconstituted justice systems in post-conflict jurisdictions? As O’Rourke notes:

The very process of formulating a campaign for legal change means translating social and political problems, which require dramatic social and political responses, into legal deficiencies that require incremental technical change. In the process, initially radical feminist analysis tends to become flattened into reformist demands for more or 'better' law. (O'Rourke 2013a, 6)

Sexual violence against women remains a prevalent reality in most societies, notwithstanding the perceived strength or functionality of their legal systems. A vast literature exists attending to sexual violence, rape and enforcement of criminal sanctions (or lack thereof) at the domestic level (Smart 1995). A much smaller body of literature addresses a feminist perspective on utilizing criminal law to address harms experienced by women (Smart 1986; Naffine 1996; Lacey 1998). Before feminist scholars enthusiastically embrace ICL, some awareness of and reflection on the cogent critiques by feminist criminal law critics in domestic contexts might usefully be brought into play. As Buss warns:

The criminal law has always been a contradictory site for feminist activism. While the police and courts can be essential in protecting vulnerable populations living with violence, criminal law is by definition a coercive and blunt tool. It too is violent. Feminists working to address sexual violence against women in Anglo-American jurisdictions have highlighted the many limits of criminal prosecutions in rape cases. (Buss 2011, 409) 
In addressing the potential connections, if any, between developments in ICL with sexual offence law reform in domestic legal systems, some caveats are necessary (0'Rourke 2013b). What we know is that even "in countries with developed sexual offences legislation and strong women's movements, impunity for rape continues" (Westmarland and Gangoli 2011 , 8). Reforms on paper in these states have resulted from focused organizational interventions by national women's organizations, increasingly globalized discourses on the unacceptability of violence against women and the pressure of international oversight via human rights treaty obligations. Despite advances, impunity for sexual violence and rape persists, as is evidenced by low victim reporting, a significant drop off in pursuit of proceedings by police from reporting to investigation, low conviction rates and desultory sentencing practices (Tang 1998). The legislative expansions tracked by this article point to norm augmentation 465 but say little about effectiveness or enforcement, indicating that optimism may be premature for the work that will be done by these norms in a complementarity context.

Despite decades of domestic lobbying in many highly-sophisticated legal systems, efforts to address violence against women through statutory regu470 lation and modification has yielded, relative to other criminal law rule augmentation, modest results (Thornton 1991; Tempkin and Krahe 2008). The range of offences against women as articulated by domestic criminal law statutes remains rather static, and undergirding doctrines and myths (fresh complaint, mistake of fact, passivity/fighting) continue to exercise influence on the outcomes of any criminal proceeding. At the national level, in contrast to the expansive normative developments contained in the ICC Statute, substantial efforts have been required to bring about minimal changes in existing statutory standards (Westmarland and Gangoli, 2011). The comparative picture of rape law reform across many states reveals substantial efforts to reform the "rape" piece of the sexual assault legal framework. However, the translation of legal change to practical outcomes has been extremely limited.

The tracking of significant legislative efforts across all ICC States Parties shows developing prohibitions on a range of sexual offences including trafficking, female genital mutilation, forced marriage, early marriage, domestic violence, stalking, violence against women and penetrative sexual harm. There is little available evidence that lobbying and norm articulation at the international level has intersected with domestic criminal law reform efforts. No obvious organic (or any) relationship exists between the two, indicating 490 processes of legal change that are multidirectional and currently entirely divorced from one another, working to different kinds of compliance incentives. Yet, there is fruitful room for further exploration of the momentum that may be generated from the engagement of states with ICL and potential downstream consequences for more fulsome domestic regulation of genderbased harms. 
Women experience violence in multiple forms in many societies (Brownmiller 1993). Much feminist theory has rightly concentrated on bringing intimate violence into the public domain and ensuring in policy terms that its private categorization does not mean that it is unregulated by the state (Estrich 1988). Despite such attempts to capture the range and depth of violent harms experienced by women, coverage remains patchy and incomplete in all domestic legal systems (Dolkart 1994), notwithstanding decades of advocacy and legal reform efforts. Attending to the violent experiences of women through law has evident pitfalls, not least that the translation of harms to criminal sanction frequently produces multiple unintended consequences, including the re-inscribing of dependency, victimhood and marginalization texts. All of these pitfalls shape the ways in which we can and should expect complementarily to work for women, and limit the ways domestic legal systems will effectively respond to gendered harms.

While the analysis advanced here requires further site-specific exploration to understand the causality of domestic lawmaking, observers should be wary of assuming that "more" equals "better." Proliferation may simply be the functional outworking of treaty ratification, but says little about domestic efficiency or buy-in. It may continue to perpetrate the cold distinction between norms that are viewed as "international" and parachuted into domestic legal systems, and those viewed as integral and necessary to the completion of domestic criminal law integrity. That stated, we should not merely dismiss this rapid accumulation of legal norms as unimportant. Norm accumulation confirms the ongoing centrality and expansion of criminal law models for addressing multiple forms of violence against women. Legislative developments are indicative of ongoing contestation and naming of gendered harms, a process that remains in constant motion. From a pragmatic ICC perspective, the proliferation of domestic norms addressing a range of gender-based harms may offer the means to embed a more nuanced (and ultimately effective) form of complementarity at the national frontline. For this reason, paying close attention to domestic developments provides insight into the nuances of domestic and international interactions as well as giving us a granular understanding of the complementarity terrain.

Fionnuala Ni Aolain University of Minnesota Law School 344 Walter F. Mondale Hall 229 - 19th Ave South Minneapolis, MN 55455, USA 
1 The data contained in Appendix I track domestic legislation addressing a wide range of gender-based harms enacted after states signed the ICC Statute. I acknowledge that given linguistic and translation challenges, there may be further legislation in some of the states listed that were not identified by the desk-based research. The cut-off date for both state signature and domestic legislation included in this analysis is April 2012. Not all the legislation identified involves criminal sanctions, although the predominant motif of the legislative measures across jurisdictions is criminal accountability.

2 Convention Relative to the Protection of Civilian Persons in Time of War, 6 U.S.T. 3516, 75 U.N.T.S. 287 Article 27, 2 (1950).

3 Protocol Additional to the Geneva Conventions of 12 August 1949, and Relating to the Protection of Victims in International Armed Conflicts, Annex I, U.N. Doc. A/ 32/144 (8 June 1977), in 16 I.L.M. 1391 (1977).

4 Case No IT-94-1-T judgment of 7 May 1997.

5 Case No IT-96-21 judgment of 16 November 1998.

6 Case No IT-95-17/1-T judgment of 10 December 1998.

5607 Kunarac: Prosecutor v. Dragoljub Kunarac, Radomir Kovac, Zoran Vukovic, IT96-23-T and IT-96-23/1-T (30 March 2000).

8 Krstic: Case No. IT-98-33-T, judgment of 2 August 2001.

9 Prosecutor v. Akayesu, ICTR-96-4-T Judgment of 1 June 2001; Prosecutor v. JeanPaul Akayesu, Case No. ICTR-96-4-T, Judgment, ๆ596, (2 September 1998).

56510 ICTR-99-52-T, Trial Chamber, 3 December 2003.

11 Barayagwiza, Ngeze and Nahimana: ICTR-99-52-T, Trial Chamber, 3 December 2003.

12 Gacumbitsi: ICTR-99-52-T, Trial Chamber, 3 December 2003: paras 114 and 1079.

13 Judgment, Prosecutor v. Brima, Karama and Kanu, SCSL, Appeals Chamber, 22 February 2008. Judgment, Prosecutor v Sesay, Kallon and Gbao, SCSL, Trial Chamber, 2 March 2009.

14 Noting the national statistics for sexual assault in Australia, found at http://www. ausstats.abs.gov.au/ausstats/subscriber.nsf/0/8612E58B8BCDCF9DCA2578B7001 19690/\$File/45100_2010.pdf; for Canada (to 2009), http://www.statcan.gc.ca/ pub/89-503-x/2010001/article/11416-eng.pdf; and for England and Wales (2010-2011), http://www.homeoffice.gov.uk/publications/science-researchstatistics/research-statistics/crime-research/hosb1011/hosb1011?view=Binary

15 Rome Statute for the International Criminal Court, 17 July 1998, 2187 UNTS 90, entered into force 1 July 2002 ("ICC Statute").

58016 Ibid., art. 7(1)(g).

17 For example, in Australia those statutes were the International Criminal Court (Consequential Amendments) Act 2002 and inserted new divisions in the Commonwealth Criminal Code (Cth) and the International Criminal Court Act 2002 (Cth), which made provisions for the surrender of suspects and the provision of other forms of support to the ICC. 
18 Summary of the Decision on the Admissibility of the case against Mr. Abdullah AlSenussi 11 October 2013, http://www.icc-cpi.int/en_menus/icc/press\%20and\% 20media/press\%20releases/Documents/pr953/Summary\%20AL-Senussi\%20Engli sh.pdf, and Summary of the Decision on Admissibility of the case against Mr. Gaddafi 21 May 2014, http://www.icc-cpi.int/en_menus/icc/situations\%20and\% 20cases/situations/icc0111/related\%20cases/icc01110111/Documents/Summaryof-the-Decision-on-the-admissibility-of-the-case-against-Mr-Gaddafi.pdf ICC-01/11-01/11, Pre-Trial Chamber I, 5 June 2012.

\section{Acknowledgements}

A number of individuals provided feedback on this paper, including Martha Minnow, Naomi Cahn, Eilish Rooney and Christine Bell. My thanks to Mary Rumsey at the University of Minnesota Law School Library for sourcing the national data that underpins this paper, and to Emily Hutchinson and Laura Matson for research assistance.

Professor Fionnuala Ní Aoláin is concurrently the Dorsey and Whitney Chair in Law at the University of Minnesota Law School and Professor of Law at the University of Ulster's Transitional Justice Institute in Belfast. She has published extensively in the fields of emergency powers, conflict regulation, transitional justice and sex-based harms in times of war. Her books include Law in Times of Crisis (CUP 2006) (awarded the American Society of International Law's Certificate of Merit for creative scholarship 2007); On the Frontlines: Gender, War and the Post Conflict Process (2011); and Guantanamo and Beyond (CUP 2013). In 2003, she was appointed by the UN SecretaryGeneral as Special Expert on promoting gender equality in times of conflict and peace-making. In 2011, she completed a study on Reparations for Conflict-Related Sexual Violence for the OHCHR and UN WOMEN. She chairs the Women's Program of the Open Society Fund.

\section{REFERENCES}

Boister, N., and R. Cryer. 2008. The Tokyo International Military Tribunal: A Reappraisal. Oxford: Oxford University Press.

Brownmiller, S. 1993. Against Our Will: Men, Women and Rape. New York: Ballantine Publishing Group.

Burke-White, W. 2008. "Proactive Complementarity: The International Criminal Court and National Courts in the Rome System of International Justice." Harvard International Law Journal 49 (1): $53-108$. 
Buss, D. 2010. "Learning Our Lessons? The Rwanda Tribunal Record on Prosecuting Rape." In Rethinking Rape Law: International and Comparative Perspectives, AQ8 edited by C. McGlynn, and V. E. Munro, 61-75. Abingdon: Routledge.

Buss, D. 2011. "Performing Legal Order: Some Feminist Thoughts on International Criminal Law.” International Criminal Law Review 11 (3): 409-423. doi:10.1163/ 157181211 X576339

Chappell, L., R. Grey, and E. Waller. 2013. “The Gender Justice Shadow of Complementarity: Lessons from the International Criminal Court's Preliminary Examinations in Guinea and Colombia." International Journal of Transitional Justice 7 (3): 455475. doi:10.1093/ijtj/ijt018

Copelon, R. 2003. "International Human Rights Dimensions of Intimate Violence: Another Strand in the Dialectic of Feminist Lawmaking." American University Journal of Gender, Social Policy and Law 11 (2): 865-876.

Dolkart, J. L. 1994. "Hostile Environment Harassment: Equality, Objectivity, and the Shaping of Legal Standards." Emory Law Journal 43 (1): 151-244.

Easteal, P. 2011. "Sexual Assault Law in Australia: Contextual Challenges and Changes." In International Approaches to Rape, edited by N. Westmarland, and G. Gangoli, 13-34. Chicago: University of Chicago Press.

El Zeidy, M. M. 2002. "The Principle of Complementarity: A New Machinery to Implement International Criminal Law." Michigan Journal of International Law 23 (4): $869-976$.

Engle, K. 2012. “Celebrity Diplomacy and Global Citizenship.” Celebrity Studies 3 (1): 116-118. doi:10.1080/19392397.2012.644728

Enloe, C. 2004. The Curious Feminist: Searching for Women in a New Age of Empire. Berkeley: University of California Press.

Estrich, S. 1988. Real Rape. Cambridge, MA: Harvard University Press.

Ferme, M. C. 2013. “'Archetypes of Humanitarian Discourse': Child Soldiers, Forced Marriage and the Framing of Communities in Post-Conflict Sierra Leone." Humanity 4 (1): 49-71. doi:10.1353/hum.2013.0012

Freeman, M. D. A. 1980. "Violence Against Women: Does the Legal System Provide Solutions or Itself Constitute the Problem?.” British Journal of Law and Society 7 (2): 215-241. doi:10.2307/1409661

de Guzman, M. M. 2011. “Giving Priority to Sex Crime Prosecutions: The Philosophical Foundations of a Feminist Agenda.” International Criminal Law Review 11 (3): 515-528. doi:10.1163/157181211X576393

Howse, R., and R. Teitel. 2010. "Beyond Compliance: Rethinking Why International Law Really Matters.” Global Policy 1 (2): 127-136. doi:10.1111/j.1758-5899.2010. $00035 \mathrm{x}$

ICC-01/04-01/07-1008-Anx A Informal expert paper: The principle of complementarity in practice (2003) ("Informal Expert Paper"), at 3

Kapur, R. 2012. “Girls will be Girls: A Critical Evaluation of UN SCR 1325 and 1820.” In Third World Approaches to International Law, edited by M. Toufayan, and E. Jouannet. Durham: Duke University Press.

Kleffner, J. K. 2008. Complementarity in the Rome Statute and National Criminal Jurisdictions. Oxford: Oxford University Press. 
Lacey, N. 1998. Unspeakable Subjects: Feminist Essays in Legal and Society Theory. Oxford: Oxford University Press.

de Londras, F. 2011. "Prosecuting Sexual Violence in the Ad Hoc International Criminal Tribunals for Rwanda and the Former Yugoslavia." In Transcending the Boundaries of Law: Generations of Feminism and Legal Theory, edited by M. A. Fineman, 290 304. Abingdon: Routledge.

Meron, T. 1993. "Rape as a Crime Under International Humanitarian Law." American Journal of International Law 87 (3): 424-428. doi:10.2307/2203650

Merry, S. E. 2006. Human Rights and Gender Violence: Translating International Law into Local Justice. Chicago: University of Chicago Press.

Mibenge, C. S. 2013. Sex and International Tribunals: The Erasure of Gender from the War Narrative. Philadelphia: University of Pennsylvania Press.

Mullins, C. R. 2009. “'We are Going to Rape You and Taste Tutsi Women'; Rape during the 1994 Rwandan Genocide.” British Journal of Criminology 49 (6): 719-735.

690 doi:10.1093/bjc/azp040

Naffine, N. 1996. Feminism and Criminology. Cambridge: Polity Press.

Nesiah, V. 2013. "Feminism as Counter-Terrorism: The Seduction of Power." In Gender, National Security and Counter-Terrorism Human Rights Perspectives, edited by M. L. Satterthwaite, and J. C. Huckerby, 127-151. Abingdon: Routledge.

Nouwen, S. 2013. Complementarity in the Line of Fire: The Catalysing Effect of the International Criminal Court in Uganda and Sudan. Cambridge: Cambridge University Press.

Oosterveld, V. 2009. "Lessons from the Special Court for Sierra Leone on the Prosecution of Gender-Based Crimes.” American University Journal of Gender, Social Policy and Law 17 (2): $407-430$.

0’Rourke, C. 2013a. Gender Politics and Transitional Justice. Abingdon: Routledge.

O'Rourke, C. 2013b. "International Law and Domestic Gender Justice, or Why Case Studies Matter." In Feminist Perspectives on Transitional Justice: From International and Criminal to Alternative Forms of Justice, edited by M. A. Fineman, and E. Zinsstag, 11-42. Cambridge: Intersentia.

Pratt, K. M., and L. E. Fletcher. 1994. "Time for Justice: The Case for International Prosecutions of Rape and Gender-Based Violence in the Former Yugoslavia." Berkeley Women's Law Journal 9 (1): 77-102.

Smart, C. 1986. "Feminism and Law: Some Problems of Analysis and Strategy." International Journal of the Sociology of Law 14 (2): 109-123.

710 Smart, C. 1989. Feminism and the Power of Law. Abingdon: Routledge.

Smart, C. 1995. Law, Crime and Sexuality: Essays in Feminism. London: Sage Publications Ltd.

Snider, L. 1994. “Feminism, Punishment and the Potential of Empowerment." Canadian Journal of Law and Society 9 (1): $75-104$.

715 Snider, L. 1998. “Towards Safer Societies.” British Journal of Criminology 38 (1): 1-39.

Tang, K-L. 1998. "Rape Law Reform in Canada: The Success and Limits of Legislation.” International Journal of Offender Therapy and Comparative Criminology 42 (3): 258-270. doi:10.1177/0306624X9804200307

Tempkin, J., and B. Krahe. 2008. Sexual Assault and the Justice Gap: A Question of Attitude. Portland: Hart Publishing. 
Thornton, M. 1991. "Feminism and the Contradictions of Law Reform." International Journal of the Sociology of Law 19: 453-474.

Westmarland, N., and G. Gangoli, eds. 2011. International Approaches to Rape. Chicago: University of Chicago Press.

Women's Caucus for Gender Justice (WCGJ), 'Gender Justice and the ICC' (paper presented at the Rome Conference, Rome, Italy, 15 June-17 July 1998), 25.

ICC

\begin{tabular}{lccc} 
Country & ICC signature & ratification & Legislation and year \\
\hline Senegal & 18 July 1998 & 2 February & Domestic Violence \& FGM 1999, \\
Trinidad \& Tobago & 23 March & 6 April 1999 & Trafficking 2005 \\
& Domestic Violence 1999, Sexual \\
Offence 2000
\end{tabular}

San Marino

18 July 199813 May 1999 Domestic Violence 2008, Sexual

Harassment 2008, Sexual Violence 2008, Stalking 2008, Trafficking 2008, Violence Against Women 2008

18 July 199826 July 1999 Violence Against Women 2000, Domestic Violence 2001, Trafficking 2003, Sexual Harassment 2003, Domestic Violence 2003, Sexual Harassment 2005, Female Genital Mutilation

Fiji

29 November 29 November Domestic Violence 2003, Forced $1999 \quad 1999 \quad$ Pregnancy 2009, Sexual Violence 2009, Trafficking 2009

755 Ghana

18 July 199820 December Trafficking 2005, Domestic Violence 1999 2007, Sexual Harassment 2007

Norway

28 August 1998 16 February 2000

Belize

$\begin{array}{cc}28 \text { August } & 16 \text { February } \\ 1998 & 2000\end{array}$

Domestic Violence 2002, 2006 \& 2010, Early Marriage \&t Forced Marriage 2003, Trafficking 2003 \& 2009, Female Genital Mutilation 2004

5 April 20005 April 2000 Sexual Harassment 2000 \&t 2007, Domestic Violence 2000 \&t 2007, Trafficking 2003 


\begin{tabular}{|c|c|c|c|}
\hline Country & ICC signature & $\begin{array}{l}\text { ICC } \\
\text { ratification }\end{array}$ & Legislation and year \\
\hline Tajikistan & $\begin{array}{l}39 \text { November } \\
1998\end{array}$ & 5 May 2000 & $\begin{array}{l}\text { Trafficking } 2004 \text { \&t 2007, Violence } \\
\text { Against Women } 2005 \text { \&t } 2010 \\
\text { Trafficking } 2007\end{array}$ \\
\hline Iceland & $\begin{array}{l}26 \text { August } \\
1998\end{array}$ & 25 May 2000 & $\begin{array}{l}\text { Violence Against Women 2008, } \\
\text { Sexual Harassment } 2008\end{array}$ \\
\hline Venezuela & $\begin{array}{l}14 \text { October } \\
1998\end{array}$ & 7 June 2000 & $\begin{array}{l}\text { Domestic Violence 2007, Sexual } \\
\text { Harassment 2007, Trafficking } \\
\text { 2007, Forced Sterilization 2007, } \\
\text { Sexual Violence 2007, Violence } \\
\text { Against Women } 2007\end{array}$ \\
\hline France & 18 July 1998 & 9 June 2000 & $\begin{array}{l}\text { Trafficking 2003, Domestic Violence } \\
\text { 2004, 2005, 2006, 2007, 2009, } \\
\text { 2010 \&t 2011, Violence Against } \\
\text { Women 2005, 2006, } 2010 \text { \& 2011, } \\
\text { Female Genital Mutilation 2006, } \\
\text { Forced Marriage 2010 \&t 2011, } \\
\text { Sexual Harassment } 2010\end{array}$ \\
\hline Belgium & $\begin{array}{l}10 \text { September } \\
1998\end{array}$ & 28 June 2000 & $\begin{array}{l}\text { Domestic Violence } 2000 \text { \&t 2003, } \\
\text { Female Genital Mutilation 2000, } \\
\text { Sexual Violence 2000, Sexual } \\
\text { Harassment 2002, 2006 \& 2007, } \\
\text { Violence Against Women 2002, } \\
2006 \text { \& 2007, Domestic Violence } \\
\text { 2003, Trafficking 2005, Forced } \\
\text { Marriage } 2007\end{array}$ \\
\hline Mali & 17 July 1998 & $\begin{array}{l}16 \text { August } \\
2000\end{array}$ & Female Genital Mutilation 2002 \\
\hline Lesotho & $\begin{array}{l}30 \text { November } \\
1998\end{array}$ & $\begin{array}{l}6 \text { September } \\
2000\end{array}$ & $\begin{array}{l}\text { Sexual Violence 2003, Marital Rape } \\
\text { 2003, Domestic Violence } 2006\end{array}$ \\
\hline New Zealand & $\begin{array}{l}7 \text { October } \\
1998\end{array}$ & $\begin{array}{l}7 \text { September } \\
2000\end{array}$ & $\begin{array}{l}\text { Domestic Violence 2000, Violence } \\
\text { Against Women 2002, Domestic } \\
\text { Violence } 2006\end{array}$ \\
\hline Botswana & $\begin{array}{l}8 \text { September } \\
2000\end{array}$ & $\begin{array}{l}8 \text { September } \\
2000\end{array}$ & Domestic Violence 2007 \\
\hline Luxembourg & $\begin{array}{l}13 \text { October } \\
1998\end{array}$ & $\begin{array}{l}8 \text { September } \\
2000\end{array}$ & $\begin{array}{l}\text { Domestic Violence 2003, Female } \\
\text { Genital Mutilation } 2008\end{array}$ \\
\hline Sierra Leone & $\begin{array}{l}17 \text { October } \\
1998\end{array}$ & $\begin{array}{l}15 \text { September } \\
2000\end{array}$ & $\begin{array}{l}\text { Trafficking 2005, Domestic Violence } \\
\text { 2007, Sexual Harassment 2007, } \\
\text { Early Marriage \& Forced Marriage } \\
\text { 2007, Sexual Violence } 2012\end{array}$ \\
\hline
\end{tabular}

(Continued) 
ICC

Country

ICC signature ratification

Legislation and year

Gabon

22 December 20 September Trafficking 2001 1998

2000

Spain

18 July 199824 October Trafficking 2000 \&t 2004, Domestic 2000 Violence 2003, 2004, 2005, 2006 \&t 2007, Female Genital Mutilation

South Africa

17 July 199827 November Female Genital Mutilation 2000, 2000 Violence Against Women 2000, Trafficking 2007, Sexual Violence

Finland

7 October 1998

Sweden

Argentina

Dominica

7 October 1998

7 October 1998

6 Septem
2000 2007, Domestic Violence 2011, Sexual Harassment 2011, Stalking 2011

10 December 11 December Domestic Violence 2002 \& 2009 , $1998 \quad 2000 \quad$ Stalking 2002 \& 2006 , Trafficking 2005

Austria

8 January 1999

8 February 2001 Sexual Violence 2000, 2002, 2004 2009, Trafficking 2002 \& 2004, Female Genital Mutilation 2002 \&t 2006, Domestic Violence 2003, 2004 \&t 2009, Sexual Harassment 2004, Forced Marriage 2006, Stalking 2006 \&t 2009, Violence Against Women 2009

29 December Trafficking 2004, 2006 \& 2007, 2000 Domestic Violence 2005 28 January Trafficking 2002 \&t 2004, Sexual Violence 2005

Domestic Violence 2008 \&t 2009, Trafficking 2008, Sexual Harassment 2009, Sexual Violence 2009

12 February Domestic Violence 2002 2001

Andorra 18 July 199830 April 2001 Domestic Violence 2005, Sexual Harassment 2005, Sexual Violence 2005

Paraguay

7 October 1998
14 May 2001 No national legislation on gender violence since ICC Ratification 
ICC

860
Antigua and

Barbuda

Denmark

The Netherlands

Serbia

Nigeria

Liechtenstein

Central African Republic

Switzerland

Peru

Poland

ICC signature ratification

Legislation and year

12 0ctober 1998

7 October 1998

23 October 1998

25 September 21 June 2001 Female Genital Mutilation 2003, 1998 Domestic Violence 2004, 2007 \&t 2008, Trafficking 2007

18 July 199817 July 2001 Trafficking 2005, Domestic Violence 2007 \&t 2008

19 December 6 September Domestic Violence 2005 $2000 \quad 2001$

1 June 200027 September Trafficking 2003 2001

18 July 19982 October 2001

Domestic Violence 2001 \&t 2008, Violence Against Women 2001 \&t 2008, Marital Rape 2001, Sexual Harassment 2001, Sexual Violence 2008

7 December 3 October

Violence Against Women 2004, 19992001 Domestic Violence 2006, Female Genital Mutilation 2006, Sexual Harassment 2006

18 July 199812 October Domestic Violence 2004, 2006, 2008 2001 \& 2009, Marital Rape 2004, Sexual Violence 2004, Trafficking 2004, Stalking 2006, Violence Against Women 2009

7 December 10 November Sexual Violence 2004, 2006 \&t 2007, $20002001 \quad$ Violence Against Women 2004 \&t 2007, Marital Rape 2004, 2006 \&t 2007, Trafficking 2004, 2007 \&t 2008

13 December 12 November No national legislation on gender $20002001 \quad$ violence since ICC ratification

9 April 199912 November Domestic Violence 2005 2001 


Country

Mauritius

Macedonia

Cyprus

Panama

Democratic Republic of the Congo

ICC ICC signature ratification

Legislation and year

15 January 30 November Trafficking 2002, Violence Against $19992001 \quad$ Women 2006, Domestic Violence 2007, Stalking 2007

7 October 31 December Violence Against Women 2002, 2006 $19982001 \quad$ \& 2008, Domestic Violence 2003, 2006 \&t 2008, Marital Rape 2008, Sexual Harassment 2008, Sexual Violence 2008, Stalking 2008, Trafficking 2008

24 September 22 January 19992002

27 December 30 January 1999

2002

\section{October} 1998

7 October 1998
5 February 2002
5 February 2002

Early Marriage \& Forced Marriage 2002, Female Genital Mutilation 2003

Violence Against Women 2004, Trafficking 2005 \& 2012, Sexual Violence 2006, Domestic Violence 2006

Domestic Violence 2006 \& 2007 , Trafficking 2007

Domestic Violence 2002, Violence Against Women 2002, 2006, 2007 Et 2008, Trafficking 2004, Sexual Violence 2005

11 November 5 March 2002 Domestic Violence 2004 \&t 2007 1998

7 October 6 March 2002 Domestic Violence 2004, 2006, 1998 Marital Rape 2005, Sexual Harassment 2005, Sexual Violence 2005, Trafficking 2006, Violence Against Women 2006

15 October 7 March 2002 Female Genital Mutilation 2003, 1998 Domestic Violence 2004, Trafficking 2007

18 July 199821 March Sexual Violence 2004, Domestic $2002 \quad$ Violence 2007

8 September 11 April 2002 Forced Marriage 2006, Sexual 2000 Violence 2006 \&t 2009, Violence Against Women 2006 \&t 2009, Sexual Harassment 2009, Trafficking 2009

(Continued) 
ICC

950

Niger

955 Jordan

Mongolia

960

Bosnia and Herzegovina

Slovakia

970 Bulgaria

Romania

Ireland

Cambodia

Uganda

Brazil
Legislation and year

17 July 199811 April 2002 Female Genital Mutilation 2003 \&t 2006, Marital Rape 2003, Sexual Harassment 2003, Sexual Violence 2003, Trafficking 2006, Violence Against Women 2006 \&t 2010

7 October 11 April 2002 No national legislation on gender $1998 \quad$ violence since ICC ratification 29 December 11 April 2002 Sexual Violence 2002 \& 2005, 2000 Trafficking 2002, Violence Against Women 2002 \& 2005, Domestic Violence 2005

23 October 11 April 2002 Domestic Violence 2005, Sexual 2000 Violence 2005 \& 2007, Trafficking 2005 \& 2008 , Sexual Harassment 2005

17 July 200011 April 2002 Domestic Violence 2003, Sexual Harassment 2003, Stalking 2003, Violence Against Women 2003 \&t 2007, Trafficking 2003, Sexual Violence 2007

23 December 11 April 2002 Domestic Violence 2005 \& 2008, 1998 Trafficking 2005

11 February 11 April 2002 Trafficking 2003, Domestic Violence 1999 2005

7 July 199911 April 2002 Domestic Violence 2003, Sexual Violence 2004, Trafficking 2005

7 October 11 April 2002 Domestic Violence 2002 \& 2007, 1998 Trafficking 2004 \&t 2008, Sexual Violence 2006 \&t 2007, Female Genital Mutilation 2012

Greece $\quad 18$ July 199815 May 2002 Trafficking 2002 \& 2003, Domestic Violence 2006, Marital Rape 2006, Sexual Violence 2006

17 March 1999

14 June 2002 Trafficking 2008, Domestic Violence 2009

7 February 20 June 2002 Violence Against Women 2003, 2000 Sexual Violence 2005 \&t 2006 
ICC

995

Bolivia

Gambia

1005

Latvia

Uruguay

Australia

1010

Honduras

Columbia

1015

Tanzania

Timor-Leste

Samoa

Malawi

Djibouti
ICC signature ratification

Legislation and year

27 Octobe 1998

25 June 2002 Domestic Violence 2003, Sexual Harassment 2003, Sexual Violence 2003, Stalking 2003, Violence Against Women 2003

17 July 199827 June 2002 Trafficking 2006, Domestic Violence 2009, Sexual Violence 2009, Sexual Harassment 2012, Violence Against Women 2012

4 December 28 June 2002 No national legislation on gender 1998 violence since ICC ratification

22 April 199928 June 2002 No national legislation on gender violence since ICC ratification

19 December 28 June 2002 Sexual Violence 2002, 2004 \& 2005, 2000 Domestic Violence 2002 \& 2003 , Trafficking 2008

9 December 1 July 2002 Trafficking 2005, Domestic Violence 1998

7 October 1998

1 July 2002 2011, Stalking 2011

10 December 5 August 1998 2002

Sexual Violence 2005, Trafficking 2005

Trafficking 2002 \&t 2005, Sexual Violence 2002, 2004, 2005, 2007 Ct 2008, Sexual Harassment 2006 Et 2008, Domestic Violence 2008

29 December 20 August No national legislation on gender $20002002 \quad$ violence since ICC ratification

6 September Domestic Violence 2004 \& 2010 2002

17 July 199816 September No national legislation on gender 2002 violence since ICC ratification

2 March 199919 September Domestic Violence 2006 2002

7 October 1998

5 November 2002
Violence Against Women 2003, Trafficking 2007, Female Genital Mutilation 2009 
ICC

1040

Country

Zambia

1050

Malta

Saint Vincent and the Grenadines

Barbados

1055

Albania

Afghanistan

1060

Lithuania

Ghana

1065

Georgia

1070 Burkina Faso

Congo

Burundi

1075 Liberia
ICC signature ratification

Legislation and year

17 July 199813 November Female Genital Mutilation 2005 \& 2002 2011, Sexual Harassment 2005 \&t 2011, Trafficking 2005, 2008 \&t 2011, Domestic Violence 2011, Early Marriage \& Forced Marriage 2011, Sexual Violence 2011, Stalking 2011, Violence Against Women 2011

8 March 200013 November Trafficking 2004, Domestic Violence 2002 2006 \& 2007 , Sexual Violence 2007 \& 2008

17 July 199829 November Domestic Violence 2006 2002

3 December No national legislation on gender 2002 violence since ICC ratification

8 September 10 December No national legislation on gender $2000 \quad 2002 \quad$ violence since ICC ratification

18 July 199831 January Trafficking 2004 \& 2008, Domestic 2003 Violence 2006

10 February Early Marriage \& Forced Marriage 2003 2009, Sexual Harassment 2009, Sexual Violence 2009, Violence Against Women 2009

10 December 12 May 2003 Trafficking 2005, Violence Against 1998 Women 2011

18 July 199814 July 2003 No national legislation on gender violence since ICC ratification

18 July 19985 September Sexual Violence 2003 \&t 2006, 2003 Trafficking 2003 \&t 2006, Domestic Violence 2006, 2008, 2009 \&t 2010, Sexual Harassment 2010, Violence Against Women 2010

30 November 16 April 2004 No national legislation on gender 1998 violence since ICC ratification 17 July 19983 May 2004 No national legislation on gender violence since ICC ratification

13 January 21 September No national legislation on gender $19992004 \quad$ violence since ICC ratification 17 July 199822 September Trafficking 2005, Sexual Violence 20042006 
ICC

1085

Comoros

Saint Kitts and Nevis

Montenegro

Chad

Japan

Madagascar

1110

Suriname

Cook Islands

Chile

Bangladesh
11 August 15 March 1999 2005
Legislation and year

28 December 24 September Trafficking 2005, Domestic Violence 200020042008 , Sexual Violence 2008 \&t 2010, Violence Against Women 2008 \&t 2010

Violence Against Women 2006, Marital Rape 2006, Sexual Harassment 2006, Sexual Violence 2006, Trafficking 2006, Female Genital Mutilation 2011

8 September 12 May 2005 Violence Against Women 2007 \& 2000 2010, Domestic Violence 2010, Trafficking 2010

7 September 28 October Trafficking 2005, Domestic Violence $2000 \quad 2005$ 2007, Femicide 2007, Marital Rape 2007, Sexual Harassment 2007, Sexual Violence 2007

22 September 18 August No national legislation on gender $20002006 \quad$ violence since ICC ratification

22 August No national legislation on gender 2006 violence since ICC ratification

23 October No national legislation on gender 2006 violence since ICC ratification

20 October 1 November Sexual Violence 2007 19992006

17 July 2007 Domestic Violence 2007

18 July 199814 March No national legislation on gender 2008 violence since ICC ratification

15 July 2008 Marital Rape 2009, Sexual Violence 2009, Domestic Violence 2009

18 July 2008 No national legislation on gender violence since ICC ratification

11 September 29 June 2009 Femicide 2010, Domestic Violence 1998 2010, Trafficking 2011

Czech Republic $\quad 13$ April 199921 July 2009 No national legislation on gender violence since ICC ratification

16 September 23 March

Domestic Violence 2010 19992010

28 December 10 August No national legislation on gender $2000 \quad 2010 \quad$ violence since ICC ratification

Saint Lucia
No national legislation on gender violence since ICC ratification 


\begin{tabular}{|c|c|c|c|}
\hline Country & ICC signature & $\begin{array}{c}I C C \\
\text { ratification }\end{array}$ & Legislation and year \\
\hline Moldova & \multirow[t]{3}{*}{$\begin{array}{l}8 \text { September } \\
2000\end{array}$} & $\begin{array}{l}12 \text { October } \\
2010\end{array}$ & Domestic Violence 2010 \\
\hline Grenada & & 19 May 2011 & $\begin{array}{l}\text { No national legislation on gender } \\
\text { violence since ICC ratification }\end{array}$ \\
\hline Tunisia & & 24 June 2011 & $\begin{array}{l}\text { No national legislation on gender } \\
\text { violence since ICC ratification }\end{array}$ \\
\hline Philippines & \multirow[t]{2}{*}{$\begin{array}{l}28 \text { December } \\
2000\end{array}$} & $\begin{array}{l}30 \text { August } \\
2011\end{array}$ & $\begin{array}{l}\text { No national legislation on gender } \\
\text { violence since ICC ratification }\end{array}$ \\
\hline Maldives & & $\begin{array}{l}21 \text { September } \\
2011\end{array}$ & Domestic Violence 2012 \\
\hline Cape Verde & \multirow[t]{3}{*}{$\begin{array}{l}28 \text { December } \\
2000\end{array}$} & $\begin{array}{l}10 \text { October } \\
2011\end{array}$ & $\begin{array}{l}\text { Domestic Violence 2011, Violence } \\
\text { Against Women } 2011\end{array}$ \\
\hline Vanuatu & & $\begin{array}{l}2 \text { December } \\
2011\end{array}$ & $\begin{array}{l}\text { No national legislation on gender } \\
\text { violence since ICC ratification }\end{array}$ \\
\hline Guatemala & & 2 April 2012 & $\begin{array}{l}\text { No national legislation on gender } \\
\text { violence since ICC ratification }\end{array}$ \\
\hline
\end{tabular}

